\title{
David Cameron's EU Renegotiation and Referendum Pledge: a Case of Déjà vu?
}

\author{
Julie Smith $^{1}$ \\ Dr Julie Smith (Baroness Smith of Newnham) \\ Robinson College \\ Cambridge \\ CB3 9AN \\ jes42@cam.ac.uk
}

\begin{abstract}
:
The United Kingdom's relationship with the European Union has long been fraught, creating tensions with European partners and dividing the main political parties. To try to overcome internal divisions in the Labour Party, Harold Wilson sought to renegotiate the UK's terms of membership and then held a referendum on whether the country should stay in. The result - a two to one majority of remaining - was thought to have ended the question marks over British membership definitively. Four decades later, it was the Conservatives who were divided over Europe and Prime Minister David Cameron, in what appeared to be almost a carbon copy of Wilson's actions, promising reform, renegotiation and a referendum. Yet the stakes in 2016 were rather higher than in 1975 and the challenges far greater - the more multi-faceted and institutionalised nature of the EU rendered the debate, and the potential costs and benefits, more complex. This article assesses the similarities between the two prime ministers' decisions to renegotiate the UK's terms of membership and the frameworks established for the ensuing referendums and notes significant differences, which render over-interpreting the parallels a risky business.
\end{abstract}

Key words: United Kingdom and the European Union; 1975 referendum; EU renegotiation; 2016 EU referendum; David Cameron; Harold Wilson

\footnotetext{
${ }^{1}$ Dr Julie Smith is Director of the European Centre in the Department of Politics and International Relations at Cambridge University and a member of the House of Lords. She is grateful to students and colleagues across the EU for comments on some of the arguments, which have been rehearsed in lectures, and to Geoffrey Edwards, Mathias Haeussler, Helen Wallace, William Wallace and David Yates for comments on earlier drafts. Any errors remain her own.
} 
'And as the Cabinet agreed on Saturday, the government's position will be to recommend that Britain remains in this reformed European Union' (Cameron 2016b, col. 24). Thus, David Cameron told the House of Commons that, after nine months of renegotiation with European Union (EU) partners, he now advocated that the UK should vote to remain in the EU in a referendum to be held on $23^{\text {rd }}$ June 2016. It all seemed eerily familiar: a Prime Minister leading a divided party with just a small parliamentary majority renegotiating the UK's membership of 'Europe' before calling a referendum on whether to stay in and waiving cabinet responsibility on the matter in order to secure the future of his own party, just has Labour PM Harold Wilson had done in 1975. The expectation had been that, like Wilson, Cameron would come back with precious little to show for his pains but nonetheless would argue he had secured enough to recommend that the UK should now remain in the EU, creating a carbon copy of the 1975 experience, albeit with the Conservatives rather than Labour now suffering the deepest divisions over Europe.

Yet the reality is rather more nuanced. The 1975 referendum created two precedents and provided one constitutional anomaly: it was the first national referendum to be held in the United Kingdom and provided British voters with their first opportunity to say whether or not they wished to be part of the European Community (or 'Common Market' as it was generally known) as well as being only the second time that collective cabinet responsibility had been waived. $^{2}$ Inevitably a second referendum on remaining in the EU would not be groundbreaking in the same way. The fact that it should happen at all is evidence that the decision taken in 1975 was not the end of the story as pro-Europeans assumed at the time. ${ }^{3}$ There are, however, significant parallels in the motives and choices of Labour's Harold Wilson and the Conservative David Cameron as they sought to hold their fractured parties together. The aim of this article is to analyse continuities and changes in the UK's relations with the EC/U as seen in the two episodes. Taking as its starting point the present author's 1999 evaluation of the 1975 referendum (Smith 1999), it seeks to highlight points of comparison between the approaches of Wilson and Cameron. It is based in part on extensive analysis of primary materials, including Hansard, political speeches, party manifestos and European Council conclusions, as well as insights from the author's personal experiences leading for the Liberal

\footnotetext{
${ }^{2}$ The first time was in 1931 over that other major divider of parties: free trade. See Wall 2014: 1.

${ }^{3}$ Prime Minister Harold Wilson argued that 'It means that 14 years of national argument are over.' Quoted in The Times on $7^{\text {th }}$ June 1975 and reprinted on $6^{\text {th }}$ June 2015.
} 
Democrat benches in the House of Lords on the EU Referendum Bill, which became the EU Referendum Act 2015 and paved the way for the 2016 referendum. It draws additionally on information arising from interviews with key players and numerous off-the-record meetings with UK and other EU politicians in the three years since David Cameron's landmark Bloomberg Speech in which he pledged to reform the EU, renegotiate the UK's terms of membership and hold an in/out referendum should the Conservatives win the 2015 general election.

The article argues that the decisions to renegotiate the UK's terms of membership and hold a popular vote on remaining in the European club reflected the two leaders' inability to hold their respective parties together on an issue of relatively low public salience but one that caused visceral intra-party disagreements. In both cases the leaders were willing to eschew constitutional conventions by turning to direct democracy to overcome an issue dividing their parties. Yet, as the article shows, while there are marked and indeed intentional similarities in the two cases, there were also notable differences. The stakes were far higher in 2016 than in 1975 when the EC was less influential in terms of scope and impact, and less institutionalised. As a very new member the UK was far from embedded in the Community economically or institutionally when citizens first voted on whether to stay in. A 'No' vote in 1975 would essentially have resulted in a return to a known alternative, the status quo ante 1973, in a world by then little changed since before the UK joined the EC; leaving in the second decade of the $21^{\text {st }}$ Century would be quite different. The EU had changed beyond recognition and so too had the international context in which the UK and EU function; the UK's other spheres of interest, the Commonwealth and the US had evolved in very different directions and a vote to leave the EU of 2016 would be a step into the unknown.

The article looks first at the contested nature of membership of the EC/U in British politics. It then addresses the introduction of referendums into UK constitutional politics before looking at the two sets of renegotiation and the frameworks established for the ensuing referenda. It does not seek to evaluate the campaigns nor speculate on the longer-term impact of the second referendum, which will be the subject of many subsequent articles, chapters and books. This piece seeks, rather to look at how and why David Cameron reached the point of calling a referendum in February 2016 and on what basis. 


\section{The European question in British politics before 1975}

Unlike other Member States, the UK's attitude towards the European project has consistently been ambivalent. The founding members - France, Germany, Italy and the three Benelux countries - came together for a variety of economic and security reasons in the wake of two world wars. Their rationale was clear: to secure peace and prosperity. Other states that came late to the European club similarly aspired to the ambition of a secure and peaceful Europe, and/or to the economic benefits that appeared to be associated with it. The United Kingdom's position was more complicated from the outset. Having declined to join 'the Six' in founding the European Coal and Steel Community in 1951 and the Economic and Atomic Energy Communities in 1957, the UK rapidly sought an alternative grouping, initially in the form of a wider free trade area and subsequently in the form of the competitor European Free Trade Association (EFTA) of which it was the founder and leading member (Camps 1993). These moves, which well reflected a long-standing (and ongoing) British preference for a trading bloc rather than any political alliance was greeted with hostility by French President Charles de Gaulle, who would subsequently block two British attempts to join the EC, first under Conservative Prime Minister Harold Macmillan in 1961 and then by Harold Wilson in 1967. Neither PM was dogmatically in favour of joining but each recognised the benefits that appeared to be accruing to the Six. In the case of Wilson, the deterioration of the UK economy ensured that the 1967 application was born out of weakness.

With de Gaulle's departure from the French and European stages in 1969, the UK's application was re-opened under Wilson's premiership, although the final deal on accession was concluded by his Conservative successor, the committed pro-European Edward Heath. Membership remained a contested issue, however, and the Labour Party's lukewarm support for membership while in office turned to opposition when they lost power. Thus, although the terms of accession agreed by Heath differed little from those that Labour had been discussing with the Six (Thompson 1999), Labour imposed a three-line whip to oppose accession in 1971. Nonetheless, the vote was carried thanks to 69 rebel Labour MPs voting with the Government and 20 abstaining. ${ }^{4}$ Britain finally joined the Communities on $1^{\text {st }}$ January 1973 , two decades after the founding states had come together and only after a French plebiscite on

\footnotetext{
${ }^{4}$ This point draws on material from an interview with the late Lord Roper conducted for Smith 1999.
} 
whether Britain should be allowed to join (Leigh, 1975). British voters were not afforded the same chance to vote on their own future as Heath upheld the doctrine of parliamentary sovereignty. Thus, the UK became one of the few late-comers to the EC/U to join without a popular vote.

\section{Referendums in UK politics}

The UK has traditionally asserted parliamentary sovereignty as the essential way of taking decisions, eschewing the idea of direct democracy. Indeed,'... until the 1970s, the referendum was widely regarded as unconstitutional' (Bogdanor 2005: 78). Thus, while there were divisions in the Conservative Party on the European question, they were not sufficient to cause Heath to deviate from the parliamentary model. Speaking in 1971, he argued that 'No British government could take the UK into the EC without the wish of the British people. But this should be by parliament. ${ }^{5}$ This view was widely held, as it would be two decades later when ratification of the Treaty on European Union, the so-called Maastricht Treaty, was on the agenda - ministers with views on the substance of the European question as different as Europhile Kenneth Clarke and Thatcherite Eurosceptic Michael Portillo opposed a device often construed as one for demagogues (see Major, 1999: 275). Yet, as Bogdanor has argued, the decision to hold a referendum when power is to be transferred, as it was on accession and at each treaty reform, accords with the Lockean tradition since, 'the Legislative cannot transfer the power of making laws to any other hands: for it being but a delegated power from the people, they who have it cannot pass it over to others' (Locke quoted by Bogdanor 1999: 78). Certainly other latecomers to the EU have used referendums extensively whether to accede to the EC/U or to ratify treaty reforms.

Thus, in 1972 Norway, Ireland and Denmark all held referendums on whether to join, with three quite different experiences: Norwegian voters opted to reject entry, as they would do again in 1995, whereas both the Irish and the Danes decided to accede. The fact that the decision was made by plebiscite - not for any high moral reason but because their respective constitutions required it - ensured that entry had direct popular legitimacy in Ireland and

\footnotetext{
${ }^{5}$ Edward Heath interviewed by Robin Day on Panorama, $11^{\text {th }}$ October 1971 [reshown on Sunday $26^{\text {th }}$ July 2015]. As Goodhart (1971: 13-17) makes clear, at the 1970 general election all three party leaders opposed the use of a referendum on accession.
} 
Denmark in a way that was arguably lacking in the UK. Moreover, whereas the Irish establishment and public were all in favour of joining, the Danish case was rather more akin to the British and could perhaps have provided a solution to British party political difficulties. Like the British Labour Party, the Danish Social Democrats were divided on membership, so for the accession referendum the People's Movement against the Common Market was born to fight against membership. It re-formed at subsequent referendums and for elections to the European Parliament, thereby allowing Danish parties to remain intact for domestic elections while giving voters a chance to vote for anti-integration groups in referendums and European Parliament elections.

However, like Heath, the Labour leadership was initially opposed to the idea of a referendum. Only after the party left office in 1970 and the Labour left's hostility to membership of the Community hardened did the Labour Party talk the language of renegotiation and referendum in its manifestos for the two general elections of 1974. Having originally rejected the idea of a referendum, proposed by Tony Benn, Wilson gradually recognised that the 'device of rightwingers', as he and James Callaghan saw it, despite Benn's own leftwing credentials, could be the salvation of the party. ${ }^{6}$ As former Labour MP Giles, now Lord, Radice (2015) put it:

'... as the row inside the Labour Party over Europe grew in intensity, Wilson changed his mind. He turned to the referendum as a means of uniting a divided party-yes, we were divided - and remaining in the EU. As the Foreign Secretary, James Callaghan, had predicted, it proved to be a useful "rubber dinghy".'

The Conservatives viewed the move with disdain; it was not 'a principled decision', the proEuropean Michael (now Lord) Heseltine would assert some forty years later. ${ }^{7}$

Yet while the idea of deciding on European issues via referendum had repelled the Conservatives in the 1970s, it began to gain traction in the 1990s, following the emergence of

\footnotetext{
${ }^{6}$ Lord Donoughue on The Westminster Hour, $10^{\text {th }}$ January 2016.

${ }^{7}$ Lord Heseltine reminiscing about the 1975 referendum on The Westminster Hour, 10 $0^{\text {th }}$ January 2016.
} 
the Referendum Party led by Sir James Goldsmith and the UK Independence Party (UKIP) founded by Professor Alan Sked at the time of Maastricht Treaty ratification. By the mid1990s all three main parties, Conservative, Labour and Liberal Democrat, were committed to holding a referendum before any decision to join the Euro; a pledge they repeated with regard to the ultimately aborted Constitutional Treaty. When Gordon Brown decided not to hold a referendum on the Lisbon Treaty that replaced the Constitutional Treaty, the Conservatives continued to call for one, with many expressing frustration that Cameron did not call such a poll when he became PM, even though the Treaty had by then been ratified and come into effect. The issue of EU membership became a running sore in the first half of the 2010-15 Coalition Government as Cameron's attempts to placate his rebellious backbench Eurosceptics merely fuelled their desire for more concessions (see Smith 2015; Lynch, 2015). Finally, in his now famous Bloomberg Speech of January 2013 he announced that if reelected the Conservatives would offer an in/out referendum. The decision to seek to change the UK's terms of engagement before moving to the vote made his approach look almost identical to Wilson's.

Cameron added a third ' $r$ ' to renegotiation and referendum, namely 'reform', which politicians from all parties had long agreed was required. ${ }^{8}$ The commitment proved to be a shrewd one, at least for two and half years. The 3Rs 'reform, renegotiation and referendum' coupled with the mantra 'Labour and the Liberal Democrats won't give you a say. UKIP can't give you a say. Only the Conservative Party will deliver real change in Europe - and only the Conservatives can and will deliver an in/out referendum' (Conservatives 2015: 72-3) provided a clear message to voters in the 2014 European Parliament elections and the 2015 general election. More importantly for Cameron it meant that the sceptics on his backbenches who had beleaguered his premiership until that time would mostly remain silent until after the general election, placated by the promise of the longed-for referendum. Cameron had ensured that his fractious party held together on this most contentious of issues, at least in the short term. ${ }^{9}$

\footnotetext{
${ }^{8}$ Liberal Democrat Deputy Prime Minister Nick Clegg had argued the case for European reform since being an MEP and the Labour Party also advocated reform.

${ }^{9}$ Copsey and Haughton's suggestion that 'Calling a referendum for halfway through the next parliament has been a classic strategy of party management' (Copsey and Haughton 2014: 84) may be overstating the case; this was more a matter of tactics than strategy, for both Wilson and Cameron.
} 


\section{The Renegotiations}

Wilson told his EC opposite numbers before the October election that 'he rejected any moves towards political union' (Ibid: 192) but when it came to the renegotiation, he did not seek treaty change, which then as now requires unanimity among member states. Rather, he sought to alter the UK's terms of membership of the EC, which he argued were disadvantageous 'Tory terms', even though they were essentially the same terms his own government had been discussing with the Community before Heath took office in 1970 (Thompson 1999: 2; O’Neill 2000: 9). In line with the Labour Party's manifesto commitments of October 1974, Wilson's demands focused on a set of issues that had plagued British-EC relations since before accession (Spreckley 1975: 2-3), many of which would prove equally contentious when Cameron launched his renegotiation. The result of the renegotiation, which was led by Foreign Secretary James Callaghan, was limited, a rather convoluted 'correcting mechanism to the Community budget', destined never to be triggered, being the main achievement. Years later the former German Chancellor, Helmut Schmidt, was dismissive of what he termed a 'cosmetic operation' (quoted in Young 1998: 283) and he had clearly been frustrated by Wilson's neglect of 'long-term interests' (Haeussler 2015: 774). Yet at the time, Schmidt had assisted Wilson, attending the 1974 Labour Party Conference 'to rally the troops' ${ }^{10}$ His support was, however, conditional on Wilson being willing to speak out in favour of the UK remaining in the EC (Spreckley 1975: 556).

The legacy of Wilson's renegotiation posed something of a problem for Cameron. Hailed by Wilson himself at the time as meaning he could now recommend that Britain should stay in the Common Market, the renegotiation was rapidly seen as a sham, and not just by Schmidt. Wilson had the advantage of creating a precedent in his renegotiation, few publically sought to talk down his achievements at the time and those who favoured leaving perhaps failed to notice the smoke and mirrors. That precedent meant that objective commentators and Eurosceptic detractors alike were predisposed to look at Cameron's attempts at reform and renegotiation with a rather jaundiced eye: you cannot play the same game twice and get away with it. Certainly few sceptics in 2016 would accept a smoke and mirrors deal done by Cameron. As Dominic Cummings, at the time the campaign director of the Vote Leave group, put it: 'This process has not been about trying to get fundamental change of the EU, or

${ }^{10}$ Bernard Donoughue, The Westminster Hour, Sunday $10^{\text {th }}$ January 2016. 
fundamental change of Britain's relationship with the EU, or to solve the big problems of the EU. It is about how David Cameron manages his own personal interests and the internal politics of the Conservative Party' (Bagehot 2016). Coupled with 24/7 media coverage, the rise of the internet social media and the loss of Chinese walls between media from different member states, this ensured Cameron would always have a difficult job replicating Wilson's trick. Alongside challenges from those overtly hostile to EU membership in the form of UKIP and those pro-Europeans such as the SNP who were always willing to take a swipe at the Tories despite ostensibly being on the same side of the referendum argument, Cameron's renegotiation game was always going to be more difficult to pull off domestically than Wilson's. In practice, he needed to play a high-risk three-level game: firstly, within his own party; secondly, with his opposite numbers in the 27 other Member States; last - and possibly least in his strategic thinking - with the British electorate.

Cameron asked his own party to reserve judgment on whether to support remaining in or leaving the Union until after he had completed the renegotiations, when he would make a recommendation. The issue thus became one of confidence in his leadership, quite unlike the situation with Wilson, who never invested personal capital in the issue. Sceptics swiftly broke ranks. Former Chancellor Nigel Lawson pronounced himself President of Conservatives for Britain in October 2015, stating that he had reluctantly concluded that Cameron would be unable to secure a sufficiently good deal for him to support remaining in (Guardian 2015).

Moreover, the European context rendered his objectives even harder to achieve. With migrant, Eurozone and security crises absorbing most of their energies, European leaders had little time to devote to Cameron's need for reform and renegotiation. And just as forty years of sceptic rhetoric had had their effect within the UK, so decades of British awkwardness had caused frustration among the UK's fellow EU member states. While most members were clear that they wanted the UK to remain, they were equally clear it could not be at any price. The drift to scepticism among their own populations also caused serious concern, not least in France where President Hollande was facing electoral challenges from the far-right, Eurosceptic Front National of Marine Le Pen. Reform and renegotiation that required any unpicking of the treaties would thus inevitably have fallen foul of other European leaders 
reluctant to see the European edifice that had been crafted by a series of package deals over several decades potentially pulled apart.

As in 1974/5, the British government looked to Germany for support. Yet however personally supportive Angela Merkel may have been of Cameron and however committed to keeping the UK in the EU, there were limits to her powers. She too had her critics and sceptics at home and despite numerous positive remarks along the lines of: 'Where there's a will', she never went as far as Cameron understood she had, namely to say that she would do 'everything' to keep the UK in. Cameron's tendency to default to bilateral Anglo-German relations to get things done during the Coalition government, even then with only limited success (see Smith 2015) would not suffice to secure the deal he hoped to achieve. He had to convince $27 \mathrm{EU}$ colleagues, each of whom would have to agree to the renegotiation package, as well as the European Parliament, which would be required to agree consequential secondary legislation arising from the renegotiations, of the merits of his case for reform and renegotiation. This would be a rather more onerous challenge than Wilson's, Merkel's behind-the-scenes help notwithstanding.

Thus, after securing re-election in May 2015, Cameron, along with Chancellor of the Exchequer George Osborne, Foreign Secretary Philip Hammond and Europe Minister David Lidington, promptly began a tour of capitals to discuss the government's demands. Like Wilson before him, Cameron focused extensively on his party's manifesto commitments, which had already highlighted areas of concern to be addressed. Again like his predecessor, he was reluctant to put his demands formally on paper, precisely because he did not want to show his hand too soon, either to his European colleagues or the Eurosceptics at home. His detractors, both British commentators and politicians, especially in his own party, and his EU opposite numbers, complained that Cameron's demands were not clear, despite the fact that they had been flagged up in his Bloomberg speech and repeated in the 2015 general election manifesto. Inevitably EU colleagues were not impressed by the idea that they should go to look at speeches and manifestos, as the UK allegedly told them to do, preferring Cameron to make a direct case to them. ${ }^{11}$ He finally did this on $10^{\text {th }}$ November 2015 in a letter to

\footnotetext{
${ }^{11}$ These frustrations came up in numerous meetings the present author had with politicians and officials from various EU member states over the summer and autumn of 2015.
} 
European Council President Donald Tusk and in a lecture at Chatham House. There, he harked back to his Bloomberg Speech, outlining his four 'baskets' of demands: economic governance, sovereignty, competitiveness, and welfare/immigration.

Neither his speech nor his letter to Tusk elaborated much on what informed scholars and journalists had already picked up about the renegotiation but they did appear to meet the demands of those seeking some clarity on the issue. Reform and renegotiation appeared to go hand-in-hand for Cameron, as many of the interwoven strands linked them closely together. 'Reform' was not seen as a one-off occurrence, but, rather, as part of the continuous process of European integration, as something that Britain could only affect by remaining a member. Cameron, aware that his demands should not simply be seen by EU partners as a unilateral wish-list for the UK, also made clear that some, if not all, of these demands would benefit other member states too, just as Wilson had done (Haeussler 2015: 775). ${ }^{12}$ Thus on sovereignty he was seeking an enhanced role for national parliaments, which parliaments in many EU states sought, ${ }^{13}$ alongside subsidiarity to which the EU has been formally committed since the 1993 Maastricht Treaty. A request for the UK to be exempted from the commitment to 'ever-closer union' was potentially more tricky but since the UK had long demonstrated its adherence to this concept only in the breach, and given the general drift away from the federal vision in Europe, this did not appear too difficult to achieve. The drive for competitiveness was in line with long-standing British support for the internal market, and wholly in line with the reforms and moves to reduce regulation already being undertaken by the Juncker Commission and hence needed little renegotiation.

Potentially more complex was the idea that there should be no discrimination between Eurozone and non-Eurozone countries, alongside a recognition that some states would remain permanently outside the common currency. This would be an admission by the Union that the divide between the Eurozone ins and outs would be permanent, not transitional as had long

\footnotetext{
${ }^{12}$ Donoughue (1993: 196-7) argued, for example, that the corrective mechanism had the merit of being 'applicable to all members and not just a special exemption for the UK' and hence 'acceptable'.

${ }^{13}$ While the Lisbon Treaty was heralded as giving new powers to national parliaments, by 2015 there was a consensus that the rules associated with the new procedures did not work well. Thus there were calls for reforms to the yellow card system, although arguably the problem was that parliaments did not use their existing powers effectively.
} 
been expected. However, Cameron stressed that his demands would be to the benefit of all. It was a point he reiterated at Davos in January 2016:

'I want the Eurozone to be a success...I don't want to stand in the way of things that need to be done to make the Eurozone a success... what we need is an organisation that is flexible enough so that you can be a success if you're not in the euro, or a success if you are in the euro, and fair rules between the two' Cameron 2016a).

In the event, Cameron secured what he was asking for in this area. The fourth basket, an attempt to reduce numbers of EU nationals coming to the UK to claim welfare benefits was the most controversial area for discussion, since it would have direct effects on the nationals of other EU member states, especially from Central and Eastern Europe.

While Cameron (2016a) argued that his approach offered 'a very carefully thought through plan, and one that can bring great benefits not just for Britain, but for Europe', many fellow parliamentarians begged to disagree. The list of four baskets was met with some derision in the House of Commons when Europe Minister David Lidington was sent to the despatch box to make a statement following the PM's own appearance at Chatham House and the publication of his letter to Tusk. Sir William Cash, the long-standing Chairman of the House of Commons European Scrutiny Committee called it a 'pig in a poke' (House of Commons Hansard 10 November 2015, col. 229). For those determined to leave the EU the situation was straightforward: 'It is perfectly clear, no matter which party you represent, that the Prime Minister's renegotiation is of very little consequence. Nothing major nor fundamental is even on the table, nor up for debate' (Farage et al 2016). Yet, for pro-Europeans within the Conservative Party it was essential to stress the significance of the potential outcome of the negotiations. They were not intended to win over the likes of UKIP leader Nigel Farage or Tory Eurosceptics such as Liam Fox and Bernard Jenkin who were wedded to 'Brexit'; they were intended to persuade those in the Conservative Party and the country at large who had either not made up their minds on the existential remain/leave question or who were sceptical 
but open to persuasion - seemingly a sizeable section of both constituencies, at least when Cameron commenced his talks. ${ }^{14}$

Cameron's EU colleagues stressed the fact that the demands posed some considerable difficulties, thereby implying they were rather more substantive in practice than the sceptics were willing to acknowledge. ${ }^{15}$ In particular, moves to change the rules on EU nationals claiming benefits were met with hostility by some leaders. Nonetheless, Cameron (2016a) hoped to secure a deal that he could recommend to his party and then to the country in the referendum that would follow just as Wilson had done before him. And so it proved. Late on $19^{\text {th }}$ February 2016 European Council President Donald Tusk announced there was a deal very much along the lines outlined by Tusk two weeks previously, and acceptable to the PM. He had secured commitments on non-discrimination for non-Eurozone members, exemption from 'ever closer union', a red card for national parliaments, improved competitiveness and changes to reduce EU nationals' ability to secure welfare benefits. And the deal would be lodged with the UN to be interpreted under international law. The following day the Cabinet agreed to recommend that, on the strength of the deal, the UK should remain in the EU. Immediately after the Cabinet meeting ended, so too did the temporary truce that had pervaded the Conservative Party. After all it was the deep divisions within their own parties that prompted both Cameron, and Wilson, to call a referendum in the first place and the referendum pledge had merely frozen differences rather than ending them; now the battle could begin in earnest.

\section{Setting the terms of referendums}

The innovative nature of the 1975 referendum enabled Wilson essentially to set his own rules of engagement for the plebiscite - there was no precedent to follow and few formal rules. The legislation for the referendum itself was passed only after the renegotiation had been completed in March 1975 (Donoughue 1993: 196). In marked contrast, in order to demonstrate there could be no back-sliding on his commitment, David Cameron introduced the legislation to permit his promised referendum in June 2015. The ensuing European Union Referendum Act 2015 received Royal Assent on $17^{\text {th }}$ December 2015 after lengthy debate in

\footnotetext{
${ }^{14}$ On public opinion see inter alia Goodwin and Milazzo 2015.

${ }^{15}$ For a useful analysis of the demands, see von Ondarza 2016.
} 
both Houses of Parliament. Much of the debate harked back to the experience of the 1970s, as sceptics sought to right the wrongs of that vote and pro-Europeans looked to emulate aspects they believed had worked well (Smith, forthcoming). In addition, the Political Parties, Elections and Referendums Act 2000 (PPERA) provided a more heavily regulated template for any UK-wide referendum than had been envisaged in the 1970s.

The PPERA 2000 legislation sets out the rules for referendums, including the role of the Electoral Commission in advising on the question, financial matters such as spending limits and permitted participants (those who have a right to register and to donate money) and rules on 'purdah', a period during which the government and other public bodies may not campaign. Debate during the passage of the legislation thus centred on the referendum question itself, rules on purdah, financial rules and the nature of the franchise and would in turn shape the terms of the subsequent referendum debate proper (Smith, forthcoming).

\section{The question and the franchise}

The language of the 1975 referendum question - 'Do you think that the United Kingdom should stay in the European Community (the Common Market)?' (Butler and Kitzinger 1996: 1; emphasis added) - was clear and straightforward but arguably skewed towards the status quo. The anti-marketeers were unhappy with the question that had been asked in 1975, preferring something like 'Should the UK be a member...?' (Smith 1999: 53-4). The Government initially proposed a similarly small-c conservative question in 2015: 'Should the United Kingdom remain a member of the European Union?' However, it accepted the recommendation of the Electoral Commission to use the more clumsy formulation of 'Should the UK remain a member of the European Union or leave the European Union?' The answers then being 'Remain a member of the European Union' and 'Leave the European Union'. ${ }^{16}$ The Electoral Commission deemed this wording to be the most balanced on the basis of its research; questions such as 'Should the UK be a member of the European Union?' which might on first reading appear more neutral were rejected on the grounds that some respondents were not aware that the UK was a member of the EU (Electoral Commission 2015). While there were moves to enfranchise 16 and 17 year-olds as happened in the

\footnotetext{
${ }^{16}$ In Wales the question was to be written in both English and Welsh.
} 
Scottish independence referendum as well as EU nationals resident in the UK and UK nationals who had been living elsewhere in the EU for fifteen years or more, the legislation finally adopted was based on the Westminster franchise, with only two minor additions peers of the realm and residents of Gibraltar who would be entitled to vote in elections to the European Parliament (EU Referendum Act 2015, section 2). Thus UK and Commonwealth citizens aged 18 and over would have the right to vote under this legislation but EU nationals living and working in the UK thanks to acquired free movement rights do not (unless they happen to be Irish for whom special rules apply or from the other two EU/Commonwealth states: Cyprus or Malta). Technically similar to the franchise used in 1975, the ramifications in 2016 were rather different since the 1993 Maastricht Treaty had enshrined certain citizenship rights which meant that some UK nationals resident abroad and EU nationals resident in the UK on the basis of their treaty rights would not be permitted to vote even though they would be particularly affected by a vote to leave the EU.

\section{The Political Actors}

In the 1970s the Foreign and Commonwealth Office identified six broad groups of pro- and anti-Marketeers. ${ }^{17}$ Those who wished to remain fell into three categories - i) federalists such as Edward Heath and Roy Jenkins; ii) surrogate imperialists such as Duncan Sandys who had given up on the US as an ally and turned to Europe; and iii) those who believed there was no alternative to membership (TINAs), mostly pragmatists such as Harold Wilson and James Callaghan. Those who sought to leave the Community also fell into three broad groups: iv) nationalists of left and right, including left-wing economists who believed in 'Socialism in one country' such as Lord (Nicky) Kaldor and Lord (Tommy) Balogh, and little Englanders best exemplified by Enoch Powell; Scottish and Welsh nationalists were officially also opposed to membership, although as with other parties, some members broke ranks on an issue that divided parties of government and opposition then as now; v) Liberal Internationalists - not normally Liberals but rather left-leaning Labour politicians such as Judith Hart and Peter Shore who rejected the European Community as a rich man's club, while free-market economic liberals also objected to the regulation they believed the EC

\footnotetext{
${ }^{17}$ This schema draws on internal descriptions used in the Foreign Office in the 1970s and discussed in greater detail in Smith 1999. The author is grateful to Geoffrey Edwards for this information, which provided the inspiration for both articles.
} 
brought; finally, vi) Atlanticists such as right-wing Labour MP Bruce George favoured Nato and links with the US over European entanglement.

While the rhetoric may have changed in the intervening forty years, many of the positions espoused in the 1960s and 1970s, before and immediately after accession - and the type of person advocating them - appear to fit into that Foreign Office matrix, even if the global context had changed markedly. There were still European federalists, although they typically kept their views even quieter than did Jenkins and Heath, recognising that the language of federalism would antagonise The Daily Mail and other newspapers, which having been largely pro-European in 1975 (Seymour-Ure 1996) had nearly all become Eurosceptic thanks largely to changes of ownership. ${ }^{18}$ And while few would admit to imperialism, surrogate or otherwise, TINA perhaps best characterised the bulk of those who wished to remain in the EU in the $21^{\text {st }}$ century, including, notably, leading figures in the Conservative Party. While all would describe themselves as 'Eurosceptic', a term not yet coined in 1975, the Prime Minister, Chancellor of the Exchequer George Osborne and both of Cameron's Foreign Secretaries, William Hague (2010-14) and Philip Hammond (2014- ) believed that membership was in the best interests of the UK, even if they lacked genuine enthusiasm for the Union. Certainly they lacked the cultural affinity that characterised former deputy Prime Minister Nick Clegg's pro-Europeanism, which was a rare commodity in British politics. Yet Clegg himself was a pragmatic European - indeed, he had made the case for the EU needing 'reform' while still an MEP (Clegg 2000). Nor did Labour's position differ markedly - proEuropean federalists like Jenkins having been replaced by Euro-realists such as sometime Foreign Secretary Jack Straw and former Prime Minister Tony Blair.

Others made the case for withdrawal from the ranks of the Conservative Party - albeit from the backbenches prior to the completion of the renegotiation. These would include Atlanticists, such as former Defence Secretary Liam Fox, who vigorously pressed the argument that NATO not the EU had kept the peace in Europe. The Left also had its (rather smaller) share of leavers in 2015/16 with Kate Hoey's references to the developing world at

\footnotetext{
${ }^{18}$ Federalism is seen by many in the UK to equate with centralism and is frequently used by Eurosceptics to claim the emergence of a centralised 'superstate'.
} 
the launch of Grassroots Out (GO!) on $23^{\text {rd }}$ January 2016 reminiscent of Hart's liberal internationalist stance.

The nationalists had diverged by 2015/6. The Scottish and Welsh nationalists had changed their official positions completely in the intervening forty years. The SNP now believed that membership of the European Union was beneficial for Scotland, its identity and legal system being closer to those of mainland Europe than to England and offering the prospect of enabling it to be an independent state with a seat at the EU table along the lines enjoyed by Ireland and Denmark. ${ }^{19}$ Similarly, the Welsh nationalist party Plaid Cymru advocated ongoing membership of the EU. Meanwhile, in Northern Ireland many in the far-left nationalist Sinn Fein were keen for the UK to remain in the EU to ensure Ireland was not separated by a hard EU external border. English nationalists, often supporting UKIP, meanwhile, still tended to favour leaving the EU.

\section{The battle lines are drawn}

In 1975 the anti-Marketeers mostly came together under the National Referendum Campaign umbrella organisation with pro-Marketeers campaigning under the label 'Britain in Europe'. Those in favour of remaining in the Community were better organised and better funded than their opponents, and could count on the bulk of the political, media and business establishments. While each umbrella organisation received $£ 125,000$ from the government by way of an advertising grant, Britain in Europe was able to secure significantly more funding than the NRC: $£ 1,825,000$ to $£ 8,160$ (Butler and Kitzinger 1996: 86 and 110). It was also better able to mobilise support thanks to its strong cross-party base, which assembled leading politicians from the three main parties, whereas the antis were perceived to be a set of mavericks from the political extremes (to the extent the UK had any 'extreme' politics) not least as they included the National Front and Enoch Powell. With hindsight, it appeared that the cards were very much stacked in favour of remaining in the Community in 1975, a position compounded by the extent of positive media coverage, especially in the print media, and the extensive business backing for Britain in Europe.

\footnotetext{
${ }^{19}$ Even the SNP saw a breakaway 'leave' faction led by Jim Sillars.
} 
The situation in 2016 looked rather different as the two sides prepared to do referendum battle again. The Electoral Commission was required under the EU Referendum Act 2016 to decide which two umbrella organisations (one for Remain and one for Leave) should be the 'designated organisations' which under the terms of the Act would receive state funding and certain broadcasting and other rights. A regulated period of ten weeks was established and the government agreed there should be sixteen weeks between setting the date of the referendum and its being held to allow time for the Electoral Commission to determine the respective designated organisations (Penrose 2015).

The antis had got going much earlier, not least as for them there was no point in waiting for Cameron to conclude his negotiations before they began campaigning; most were clear he could never secure sufficient concessions to render membership acceptable. Regaining the UK's seat in the WTO (a UKIP demand), significant repatriation of powers and enhanced (parliamentary) sovereignty were not on Cameron's wish list to Tusk and the 27, calls for a 'red card' for national parliaments notwithstanding. Moreover, those who opposed the European Community had continued to make their views about the EC/U known throughout the intervening forty years, while pro-Europeans, having incorrectly assumed in 1975 that the question had been decided in perpetuity, neglected to make the on-going case for membership. This would not have mattered if the public had become reconciled to membership, as was the case in other member states. However, repeated treaty reforms, especially the Maastricht Treaty, had made the British public even more reluctant Europeans. Europe was still not a particularly salient issue for the general public, but the mood was quite negative, which assisted those most vigorously opposed to the EU for whom the EU and the associated issues of free movement and migration were of high salience. Momentum for leaving the EU thus gathered pace while support for staying in had been muted for decades, cloaked as it was in complacency.

The advantage of getting out a consistent Eurosceptic message was to some extent offset by the fragmentation of those favouring 'leave'. Within the Conservative Party alone a range of Eurosceptic groups had emerged over the years, starting with the Bruges Group dating back to Margaret Thatcher's Bruges speech of 1988. The Better Off Out group, as the name implied, favoured withdrawal, while the Fresh Start group took a more moderate position and 
the Conservatives for Britain officially asserted that they were waiting to see what David Cameron's renegotiation yielded. However, their demands for repatriating powers went far beyond the issues that the Prime Minister envisaged putting to his EU partners or could conceivably be agreed by the other member states. Hence Lord Lawson's autumn 2015 announcement that he had concluded that the PM would not be able to achieve sufficient reforms and that he would support the leave campaign, as did many of the Fresh Start Group when the starting gun for the referendum was finally triggered. Labour also had a small faction of MPs in favour of leaving the EU, most notably Gisela Stuart, Kate Hoey and Frank Field. The leader of UKIP, Nigel Farage, joined forces with Hoey and new Tory MP Tom Pursglove to write a joint letter to The Daily Telegraph in January 2016 arguing that the European issue was above party (Farage et al 2016). This point was reiterated in January 2016 when a new cross-party initiative - Grassroots Out or GO! - was launched. Conservative, UKIP, Labour and Democratic Unionist MPs and MEPs signed what they grandly called the 'Kettering Declaration', stating:

'We, the undersigned, declare that in the weeks and months ahead we shall set aside party politics and work together towards our common goal of a free and prosperous United Kingdom outside the European Union, engaged with the wider world and governed by its own laws.'

Yet if Farage was able to work with leavers from other parties, he found it more difficult to work with his sole MP, Douglas Carswell, as the two found themselves supporting rival umbrella Leave campaigns. Farage indicated his support for Leave.eu funded by businessman Aaron Banks, while Carswell put his name to Vote Leave headed by Matthew Elliot, who had been a leading figure in the successful 'No to AV' campaign in 2011. The similarity of the names and aims of the two groups 'led to critics in Westminster compare [sic] them to the "Judean People's Front" and the "People's Front of Judea" from Monty Python film "Life of Brian" (Hope 2015). While the initial expectation was that the two groups, and with them the UKIP MP and his leader, would ultimately merge into a single Leave campaign, their sparring in 2015/16 gave some respite to those who favoured remaining and who were struggling to gain traction (ibid). The provisions of PPERA and the EU Referendum Act 2015 provide for the Electoral Commission to resolve the matter should the various leave 
factions be unable to come to an agreement themselves. However while the Vote Leave campaign did secure the umbrella Leave designation from the Electoral Commission in April 2016, Leave.EU/GO! Continued their activities alongside the designated organisation. ${ }^{20}$

While slower off the mark, the remain side was not entirely silent. With the prospect of a referendum a range of pro-EU groupings began to emerge, including the proto-type umbrella remain organisation, Stronger Britain in Europe (BSE) headed by Lord (Stuart) Rose, former head of Marks and Spencer, alongside more geographically or sectorally specific groups such as Cambridge for Europe and Scientists for EU. ${ }^{21}$ Universities UK (the umbrella organisation for British Universities) launched their own campaign to remain in the Union in the summer of 2015, much to the chagrin of UKIP, which claimed there was foul play in a body seeking to stay in the EU stating its case so early despite the fact that Eurosceptic groups such as Business for Britain had been running for years. ${ }^{22}$ Labour and the Liberal Democrats both launched their individual party pro-EU campaign groups before the Government's renegotiation was complete, respectively 'Labour In for Britain' led by former Home Secretary Alan Johnson, and 'IN Together' fronted by the Lib Dems' sole surviving MEP following its routing in 2014, Catherine Bearder. Pro-remain Conservatives came together as Conservatives In with David Cameron as Patron on $24^{\text {th }}$ February, just days after the renegotiation was completed.

\section{Cabinet Responsibility}

Harold Wilson had 'a political imperative - to hold his party together' (Donoughue 1993: 199). He initially refused to waive collective Cabinet responsibility, eventually agreeing to waive it but only after Cabinet had taken its decision, which was two to one in favour of staying in on the new terms. This rapidly became a de facto agreement to waive collective responsibility throughout the government, although Wilson did not permit ministers to make hostile speeches in Parliament (Donoughue 1993: 201). Wilson did not personally have strong views on membership; he did advocate remaining once he had secured his

\footnotetext{
${ }^{20}$ The Liberal Democrats yielded few leavers, although a tiny Liberal Leave group led by former MP Paul Keetch did help ensure that the Vote Leave campaign secured the official umbrella Leave designation.

${ }^{21}$ The abbreviation was seen as something of an own goal for pro-Europeans harking back as it did to the beef crisis that had soured the UK's relations within the EU during the 1990s.

${ }^{22}$ Farage on the Today Programme on $27^{\text {th }}$ July 2015, the day of the UUK launch.
} 
renegotiation but did not stake his premiership on it. His Foreign Secretary, James Callaghan, played a crucial and positive role in the renegotiations and making the case for the UK to stay in.

David Cameron's approach was very much predicated on his own ability to secure reform and altered terms of membership, though he too relied on a key Cabinet member and possible leadership successor, George Osborne for support. Cameron demanded that his MPs and MEPs hold the party line of 'reform, renegotiation and referendum' until the negotiations were complete. Breaking ranks before the renegotiation was complete was thus taken to imply that his colleagues had no faith in his negotiations, although some peers and backbench MPs did so. Pro-EU MPs urged the PM to maintain Cabinet responsibility once the negotiations were complete since a rejection of the terms on offer would also represent lack of confidence in the PM (Field 2015). The Prime Minister however gave in to demands for collective responsibility to be waived, announcing his change of heart on $5^{\text {th }}$ January 2016 even before the negotiations had been completed (Cameron 2016). The position was a rather awkward one, very much like Wilson's, whereby the Government would adopt a position formally but ministers would not be bound by it. In theory, collective responsibility was to be waived only after the negotiations were over but in practice many MPs showed their hands virtually as soon as Cameron made his announcement. And while each Prime Minister saw half a dozen Cabinet ministers take an opposing stance, Cameron was faced with an unexpected opponent in London Mayor and a challenger to replace him as leader, Boris Johnson, who announced he would be voting to leave. This was a significant early setback for Cameron. That part of Cameron's hand was played less well than Wilson's.

\section{Eternal and emerging issues}

Many of the themes rehearsed in the years prior to accession and replayed in 1975 could be heard again as the UK prepared for its second vote on the subject (Wallace 1975, cited in Smith 1999: 44). Money in the guise of UK contributions to Community budget, jobs and sovereignty as well as the Commonwealth were debated at length in 1975, although many Eurosceptics would later claim that they believed they were joining a common market and 
knew nothing of the political ambitions associated with European integration. ${ }^{23}$ All these themes would be on the agenda forty years later, although New Zealand butter and lamb no longer featured, reflecting both changed attitudes towards the Commonwealth and, more importantly perhaps, greatly altered trade patterns as a result of over four decades of EU membership.

Free movement of people/immigration, a key driver in the renegotiation, albeit with little to show in the actual deal, was set to be a new issue on the agenda for the second referendum thanks to the large numbers of EU nationals from central and eastern Europe who had been exercising their rights of free movement since accession in 2004. The associated welfare benefits issues as well as the sheer weight of numbers of EU nationals living and working in the UK - or rather in England, the most densely populated part of the UK ${ }^{24}$ - had knock-on effects for public attitudes towards the EU. First picked up by UKIP, most noticeably via a poster-campaign during the 2010 general election in which they focused on immigration, by 2016 the issue was among the top three salient issues for voters alongside the economy and the NHS (Clarke et al 2016: 154).

Coming in the wake of a protracted refugee crisis that started in spring 2015, concerns that immigration, already a key campaign issue for many Eurosceptics, would dominate debate in the referendum affected the Prime Minister's calculations on timing the referendum. Whereas Wilson could call the referendum at a time of his own choosing in 1975, by early 2016, David Cameron found himself boxed into a corner in part of his own making, in part due to international factors outside his control. Having set $31^{\text {st }}$ December 2017 as the very final date for the referendum Cameron and his team then had to work backwards to find a suitable date, given that the UK was due to hold the rotating Council Presidency in the second half of 2017, a year in which both France and Germany were due to hold national elections. Summer 2016 thus became the preferred time for the referendum, with June the date favoured by No 10 in the hope that the referendum would occur before any more

\footnotetext{
${ }^{23}$ This sort of comment featured widely on doorsteps and in the media in the twenty years following the Maastricht Treaty, with few seeming to recall either that the vote was not to 'go into' the Common Market but too remain or that politicians like Powell and Benn did talk of sovereignty, even if pro-Europeans like Heath had been less audible on the topic.

${ }^{24}$ Attitudes and concerns in Scotland over free movement were quite different as its leaders saw the benefits for an economy that had struggled to find enough workers.
} 
significant refugee issues - and before yet another Conservative conference could be overshadowed by the European question. Thus, completing the negotiations in February allowed Cameron to go for his preferred date of $23^{\text {rd }}$ June.

One major difference between the two referendums would be the importance of what leaving the European Union would mean in practice. In 1975 it was relatively clear that a vote to withdraw would mean a return to the status quo ante. Leaving in 1975 would have required some negotiations and had an impact on the UK but nothing like the effect of attempting to disentangle the UK after more than forty years of integration during which both widening and deepening of the Union had had their effect on all Member States, and when the UK had incorporated the ever-expanding acquis communautaire into domestic law. And the world outside the Union had changed profoundly too - the Commonwealth and the United States had changed and the UK was far less central to their concerns, as the US pivoted to Asia and the old Commonwealth ties had less traction, despite the rhetoric of the sceptics. There was no clear blueprint of what life outside the EU might entail for a country that had just left. Nor, as the Leavers were quick to point out, would 'remain' necessarily imply the status quo given both the renegotiation undertaken by Cameron, which was explicitly intended to alter the relationship between the UK and the other member states but would not come into effect until after a successful vote to remain, and the fact that the EU is an ever-changing project. Hence sceptics argue that remaining does not entail the status quo as the EU needs to evolve and reform itself in light of the on-going Eurozone problems.

Thus there was a real chance that the debate could descend into hypotheticals, allowing either doomsday scenarios or unrealistically positive pictures of life outside the EU to be cast by the two sides. The Government initially argued that it should be for those who wished to leave to explain to voters what leave would mean, but it eventually accepted the logic of arguments put forward by various members of the House of Lords, the current author included, and agreed to produce a factual report on what alternatives to EU membership currently exist, which could be used to inform voters (EU Referendum Act 2015, para 7). There is also a question of what can be achieved in Article 50 negotiations should the UK vote to leave. Article 50, the provision in the Lisbon Treaty intended to provide a way for states to leave the 
$\mathrm{EU}$, is so far untried and untested, so the precise workings are subject to speculation rather than prior experience. ${ }^{25}$

Some, including Boris Johnson and former Tory leader Michael Howard, asserted that a vote to leave could trigger a second referendum, allowing the UK to secure a better deal. However, the oft-drawn analogy with the cases of Denmark and Ireland being asked to vote again after rejecting various treaties in referendums was not obviously valid. In those cases, the other member states required their affirmation in order to ratify the treaties, which must be done by unanimity. By contrast, a UK vote to leave would be something which the UK had chosen and while the other member states are not actively seeking Brexit, there is a view that the UK should not be treated more favourably by threatening to leave. ${ }^{26}$ Moreover, it is hard to see how a Prime Minister could turn to his European colleagues and say words to the effect of: 'We'd like to renegotiate - again - because I think that the British voters don't really want to leave, they just want a better deal.' Such an approach would almost certainly be rejected at the EU level given the tensions regarding the UK's awkwardness even before a vote to leave, but, crucially, also suggests a fundamental disrespect for the views of the British electorate.

There are several possible alternatives to membership for a state that wishes to be outside the EU but with access to the single market, although it is unclear that any would offer the UK what some leavers appeared to want: unfettered access to a common market without political or legal integration. Jean-Claude Piris (2016) argues there are seven different alternatives to membership, including the two most commonly referred to in debates, vis: 1) the 'Norwegian' model, more formally meaning membership of the European Economic Area, which is characterised by 'fax democracy' whereby the Norwegians are required to sign up to the bulk of the EU's acquis communautaire and to contribute to the EU's budget but have no seat at the table when the rules are decided (see Fossum 2015); ${ }^{27}$ 2) the EFTA or Swiss model, which gives Switzerland more latitude than that enjoyed by Norway but it depends on hundreds of bilateral agreements. Moreover, Switzerland is also subject to the EU rules as it

\footnotetext{
${ }^{25}$ The complexity of Art 50 became clear in the Second Reading and subsequent debates in the House of Lords.

${ }^{26}$ Senior German politician in private discussions.

${ }^{27}$ The slightly out-dated phrase comes from the anecdote that Norwegian policy-makers used to sit around the fax machine waiting for instructions from the EU.
} 
found to its cost when the EU response to a domestic referendum on immigration was to suspend Switzerland's access to EU Research funding. Piris concluded that no alternative would give the UK the sort of unfettered access to the internal market that it seeks without having to abide by certain conditions, which could plausibly be as onerous as membership but without the leverage accorded to members. Thus: 'An overarching theme is that, if the UK wants access to the single market when it has left the EU, it will have to accept ...: continued free movement of labour, and the continued supremacy of EU law over British law in the single market' (Piris 2016, p. 1). So unpalatable did these options sound that the official Vote Leave camp began to argue that access to the single market was not necessary.

\section{Conclusions}

As this in-depth comparative article has demonstrated, there are many parallels between the decisions of Harold Wilson and David Cameron to renegotiate the UK's relationship with her European partners and to grant citizens the right to decide on the future relationship rather than persist in the dogma of parliamentary sovereignty that had been invoked when Edward Heath took the UK in the European Community in 1973. This is most clearly seen in the attempt of a prime minister leading a divided party trying to resolve an issue causing deep divisions within his own party by means of renegotiating membership of the EU and allowing the people rather than parliament to decide. Many of the issues remained the same but the stakes would be much higher in 2016 than in 1975, the costs and uncertainties of leaving far greater given the changing European and global contexts.

Yet by 2016 it was clear that a referendum would not necessarily end the enduring debate over the UK's relationship with the European Union, nor yet hold divided parties together. No longer a constitutional innovation, the referendum had become the device of choice for leaders unable to tackle constitutionally divisive issues through parliamentary means. While the mantra of letting the people decide appears to enhance democracy, in practice it has become a form of party management. As in 1975, however, Cameron's referendum was unlikely to end questions over the UK's membership of the EU, especially if the decision were to remain (Glencross 2015). Whereas Jenkins and Wilson assumed that the 1975 result was definitive, the intervening forty years proved them wrong as the anti-Marketeers kept on campaigning, gradually acquiring a much broader base of support thanks to repeated treaty 
reform and decades of broken promises to allow citizens to have say on the UK's relationship with the EU coupled with growing media hostility to the EU and the reluctance of business to speak out. The very fact that leading politicians were calling for a referendum because no-one under the age of 59 had been able to vote on whether or not the UK should be a member already paves the way for further calls in the future.

Tellingly, the idea that the Scottish independence referendum had ended that question 'for a generation' was quickly disproved as nationalists rapidly talked of a vote for Brexit providing the conditions under which a second independence referendum could be triggered. A leave vote could precipitate 'Sexit' - Scottish departure from the United Kingdom. It would also have profound implications for the Republic of Ireland, for Northern Ireland and for AngloIrish relations. Moreover, the EU Act 2011 ensures that a future vote would be triggered if, or rather whenever, there is a treaty reform that would shift powers to the EU, a prospect envisaged in the new British settlement. The chances that such a vote would become a proxy for another in/out vote would surely be high.

\section{Bibliography}

d'Ancona, Matthew (2016) 'As our thoughts turn to the EU, May needs to see the bigger picture', London Evening Standard, $20^{\text {th }}$ January p.16

Bagehot (2016) 'Bagehot's notebook: An interview with Dominic Cummings', The Economist, $21^{\text {st }}$ January.

$B B C$ (2016) 'Scottish "Better In" EU campaign leaders appointed', 10" January 2016, available at: http://www.bbc.co.uk/news/uk-scotland-scotland-politics-35266663, last accessed $24^{\text {th }}$ January 2016

Bogdanor, Vernon (2005) 'Constitutional Reform in Britain: the Quiet Revolution', Annual Review of Political Science, vol. 8, pp. 73-98

http://www.annualreviews.org/doi/pdf/10.1146/annurev.polisci.8.082103.104930

Butler, David and Uwe Kitzinger (1996), The 1975 Referendum (Basingstoke and London: Macmillan Press Ltd, second edition)

Cameron, David (2015), Speech at Chatham House, $10^{\text {th }}$ November

Cameron, David (2015a), 'A New Settlement for the United Kingdom in a Reformed European Union', Letter to the President of the European Council, $10^{\text {th }}$ November

Cameron, David (2016), House of Commons Hansard 5 January col. 26 
Cameron, David (2016a), Speech to World Economic Forum, Davos on $21^{\text {st }}$ January 2016, available at: https://www.gov.uk/government/speeches/davos-2016-prime-ministers-speechto-the-world-economic-forum, last accessed on $22^{\text {nd }}$ January 2016

Cameron, David (2016b), House of Commons Hansard, 22 February 2016, col. 24

Camps, Miriam (1993) 'Missing the boat at Messina and other times?' in Brian Brivati and Harriet Jones (eds) From Reconstruction to Integration - Britain and Europe since 1945 (London and Leicester: Leicester University Press), pp. 134-43

Clarke, Harold D., Peter Kellner, Marianne C. Stewart, Joe Twyman and Paul Whiteley (2016) Austerity and Political Choice in Britain (Basingstoke: Palgrave Macmillan)

Clegg, Nick (2000) Doing less to do more: a new focus for the EU (London: Centre for European Reform)

Conservatives (2015) Strong Leadership; A Clear Economic Plan; A Brighter, More Secure Future - Party Manifesto

Copsey, Nathaniel and Tim Haughton (2014) 'Farewell Britannia? "Issue Capture" and the Politics of David Cameron's 2013 EU Referendum Pledge', Journal of Common Market Studies Annual Review, vol. 52, pp 74-89

Donoughue, Bernard (1993) ' Harold Wilson and the renegotiation of the EEC terms of membership, 1974-75: a witness account', in Brian Brivati and Harriet Jones, eds, From Reconstruction to Integration: Britain and Europe since 1945 (Leicester: Leicester University Press)

Electoral Commission (2015) Referendum on membership of the European Union: Assessment of the Electoral Commission on the proposed referendum question, available at: http://www.electoralcommission.org.uk/_data/assets/pdf_file/0006/192075/EU-referendumquestion-assessment-report.pdf, last accessed on $24^{\text {th }}$ January 2016

Eriksen, Erik O. and John Erik Fossum (2015), eds, The European Union's Non-Members Independence under hegemony? (London: Routledge)

European Council (2016) European Council meeting (18 and 19 February 2016) Conclusions, EUCO 1/16, CO EUR 1 CONCL 1, Brussels, $19^{\text {th }}$ February 2016

Farage, Nigel, Tom Pursglove and Kate Hoey (2016), 'Leaving the EU is more important than party politics', The Daily Telegraph, $6^{\text {th }}$ January 2016, available at http://www.telegraph.co.uk/news/newstopics/eureferendum/12085693/Leaving-the-EU-ismore-important-than-party-politics.html, last accessed on $11^{\text {th }}$ January 2016.

Field, Mark (2015) 'Why Ministers who want to leave the EU should resign', available at http://markfieldmp.com/news-a-articles/why-ministers-who-want-to-leave-eu-should-resign/, accessed on $10^{\text {th }}$ January 2016.

Fossum, John Erik (2015) 'Representation under hegemony? On Norway's relationship to the EU', in Erikson and Fossum 2015, pp. 153-72

Glencross, Andrew (2015), 'Why a British referendum on EU membership will not solve the Europe question', International Affairs, vol. 91, no. 2, pp. 303-17 
Goodhart, Philip (1971) Referendum (London: Tom Stacy Ltd)

Goodwin, Matthew and Caitlin Milazzo (2015) 'Britain, the European Union and the Referendum: What Drives Euroscepticism?' Europe Programme Briefing (London: Chatham House)

Gordon, Sarah (2016), 'Britain's “captains of industry” want to stay in pure trading bloc', Financial Times, $10^{\text {th }}$ January, available at http://www.ft.com/cms/s/0/4bf373be-b484-11e5b147-e5e 5bba42e51.html, last accessed on $11^{\text {th }}$ January 2016

Guardian (2015) 'Lord Lawson to lead Conservative leave campaign,' $1{ }^{\text {st }}$ October, available on-line at: http://www.theguardian.com/politics/2015/oct/01/lord-lawson-conservative-leaveeu, last accessed on $24^{\text {th }}$ January 2016.

Haeussler, Mathias (2015) 'A Pyrrhic Victory: Harold Wilson, Helmut Schmidt, and the British Renegotiation of EC Membership, 1974-5', The International History Review, vol. 37 , no. 4 , pp. 768-89.

Helm, Toby and Henry McDonald (2016), 'Two-thirds of Tory MPs want Britain to quit European Union', The Observer, $10^{\text {th }}$ January 2016, available on-line at http://www.theguardian.com/politics/2016/jan/09/tory-mps-britain-european-union-eu-brexit, accessed $10^{\text {th }}$ January 2016.

Hoey, Kate (2015), 'Why leaving the EU is a left-wing move', The Independent, $9^{\text {th }}$ October 2015, available at: http://www.independent.co.uk/voices/labour-mp-kate-hoey-why-leavingthe-eu-is-a-left-wing-move-a6687936.html, last accessed on $24^{\text {th }}$ January 2016

Hope, Christopher (2015), 'Aaron Banks' Leave.EU launches formal bid to merge with rival Vote Leave', Daily Telegraph, $23^{\text {rd }}$ November 2015, http://www.telegraph.co.uk/news/newstopics/eureferendum/12012083/Arron-BanksLeave.EU-referendum-campaign-launches-formal-bid-to-merge-with-rival-Vote-Leave.html, last accessed on $11^{\text {th }}$ January 2016

HM Government (2016) The best of both worlds: the United Kingdom's special status in a reformed European Union (London: FCO)

Jenkins, Roy (1991) A Life at the Centre (London: Macmillan London Ltd)

Kent, Nick (2016) 'Forty years on', British Influence, available at http://www.britishinfluence.org/forty_years_on, last accessed on $22^{\text {nd }}$ January 2016

Leigh, Michael (1975), 'Linkage Politics: The French Referendum and the Paris Summit of 1972', Journal of Common Market Studies, vol. 14, no. 2, pp. 157-70.

Lynch, P (2015) 'Conservative Modernisation and European Integration: From Silence to Salience and Schism', British Politics 10(2) pp 185-203

Major, John (1999) The Autobiography (London: Harper Collins)

Oliver, Tim (2015), 'To be or not to be in Europe: is that the question? Britain's European question and an in/out referendum', International Affairs, vol.1, no.1, pp.77-91 
von Ondarza, Nicolai (2016) 'Core Europe and the United Kingdom', SWP Comments 6 (Berlin: Stiftung Wissenschaft und Politik)

O'Neill, Con (2000) Britain's Entry into the European Community - Report on the Negotiations of 1970-1972 (London: Frank Cass, edited and with a foreword by Sir David Hannay).

Penrose, John (2015) HC Hansard...2061, col.

Piris, Jean-Claude (2016) If the UK votes to leave - The seven alternatives to EU membership (London: Centre for European Reform)

Radice, Lord (2015) House of Lords Second Reading of the EU Referendum Bill, Hansard, $13^{\text {th }}$ October, col, $124-5$

Renwick, Alan (2016) 'What happens if we vote for Brexit?', UCL Constitution Unit blog, available at: http://constitution-unit.com/2016/01/19/what-happens

Rifkind, Malcolm (2016), http://www.prospectmagazine.co.uk/politics/eu-referendum-couldcameron-wind-up-a-lame-duck-prime-minister-european-union-brexit

Ross, Tim (2016), 'Tory Cabinet ministers “censored” in new referendum row', Sunday Telegraph, $10^{\text {th }}$ January 2016 , available on-line at http://www.telegraph.co.uk/news/newstopics/eureferendum/12091326/Tory-Cabinetministers-censored-in-new-referendum-row.html, accessed on $10^{\text {th }}$ January 2016

Seymour-Ure, Colin (1996), 'Press' in Butler and Kitzinger 1996, pp. 214-45

Shonfield, Andrew (1973) Europe: Journey to an Unknown Destination (Harmondsworth: Penguin)

Sked, Alan (2009) 'Memoirs of a Eurosceptic' in Tom Sykes and Simon Sykes, eds, Fog in Channel...? Exploring Britain's Relationship with Europe (London: Shoehorn Publishers Ltd), pp. 51-4

Smith, Julie (1999), 'The 1975 Referendum', Journal of European Integration History, vol.5, no.1, pp.41-56

Smith, Julie (2012) 'The European dividing line in party politics' in 'Forty Years on: the UK and Europe', Special issue of International Affairs, Vol. 88, No. 6, November 2012, pp. 1277-95.

Smith, Julie (2015), 'Europe: The Coalition's Poisoned Chalice' in Anthony Seldon and Mike Finn, eds., The Coalition Effect, 2010-15 (Cambridge: CUP), pp. 372-98.

Smith, Julie (2015a), 'The United Kingdom in the Wake of the Elections: EU Membership at Stake', Lecture given at the Humboldt University on $10^{\text {th }}$ June 2015 , available at: http://www.whi-berlin.eu/tl_files/FCE/Humboldt\%20Lecture\%2010\%2006\%202015.pdf

Smith, Julie (2015b). 'The United Kingdom’ in Viola 2015, pp. 213-42 
Smith, Julie (forthcoming) 'National Parliaments and the European Union - a View from Westminster' in Davor Jancic, ed., National Parliaments after the Lisbon Treaty and the Euro Crisis: Resilience or Resignation? (Oxford: OUP)

Spreckley, Nicholas (1975), The Common Market Renegotiation and Referendum 1974-75, Parts 1 and 2 and Appendix (FCO historians)

Thomson, Lord of Monifieth (1999) 'Journey to an Unknown Destination: the British Arrival in Brussels in 1973,' The 1999 FCO Annual Lecture No. 16 (London: FCO Historians, 1999).

Viola, Donatella M. ed. (2015), Routledge Handbook of European Elections (London: Routledge)

Stephen Wall (2012) The Official History of Britain and the European Community Vol. 2 From Rejection to Referendum, 1963-75 (Routledge: Whitehall Histories)

Wall, Stephen (2014) Foreword to Spreckley (1975).

Wallace, Mark (2016) 'The pros and cons of a second EU referendum', Conservative Home, available at http://www.conservativehome.com/thetorydiary/2016/01/the-pros-and-cons-of-asecond-eu-referendum.html, last accessed on $22^{\text {nd }}$ January 2016

Wallace, William (1975) 'Europe: the changing international context - Implications for British Policy’, The World Today, May 1975, pp. 177-213

Wilkes, George and Dominic Wring (1998), 'The British Press and European Integration: 1948-1996' in David Baker and David Seawright, eds, Britain for and against Europe:

British Politics and the Question of European Integration (Oxford: Clarendon Press, 1998), pp. $185-205$

Wragge Lawrence Graham \& Co (2016) The European Union Referendum Act 2015 (on-line available @.....), 6 ${ }^{\text {th }}$ January 2016

Young, Hugo (1998) This Blessed Plot: Britain and Europe from Churchill to Blair (London: Macmillan) 